\title{
SETI and Big History: Challenge and Extension
}

Lowell S. Gustafson

Department of Political Science, Villanova University

Correspondence | Lowell S. Gustafson, lowell.gustafson@villanova.edu

Citation | Gustafson, L. (2020) SETI and Big History: Challenge and Extension. Journal of Big History, IV(2); 4 - 17.

DOI | https://doi.org/10.22339/jbh.v4i2.4210

\begin{abstract}
*
SETI is one of the significant challenges to its framework that expands the purposes of big history. Big history had exerted similar impact on world history, as did previous national histories, which in turn had impacted religious history. Big History seeks to use evidence and the best theoretical analyses to integrate studies of the cosmos, Earth, life on Earth, and humanity. SETI shares the interest in the cosmos, but examines exo-planets, astrobiology, and possible extra-terrestrial intelligence. In this article, we consider the developing relationship between the purposes of SETI and big history.

\author{
Outline \\ Introduction \\ Religious Histories \\ Political, National, and Social \\ Histories
}

\author{
World History \\ Big History
}

SETI

A Coming of Age Story

Detecting and Communication

\author{
Popular Culture \\ A Story of Endings
}

Conclusions
\end{abstract}

\section{Introduction}

The past just isn't what it used to be. It keeps changing. Where we begin our accounts of the past have varied over time. Whose histories we examine have changed. These changes come about through a process of challenge and extension, and they tell us a lot about how we understand ourselves. Political, national, and social histories challenged and changed religious and traditional histories. World history challenged and extended national histories. Big history did the same to world history. And the search for extraterrestrial intelligence (SETI) is among the challenges that implicitly call for an extension of big history.

One of humanity's defining characteristics is memory, which is different from evidence of the past. Chondrites, or meteorites that have been orbiting our sun since the formation of our solar system, provide us evidence of what happened in space over 4.5 billion years ago. Intrusions of igneous rock give us evidence of what happened millions of years ago on Earth. But we do not think that these pieces of evidence themselves remember or reflect on what they took part in long ago.

Some have contended that plants remember. ${ }^{1}$ Many animals chimpanzees, dolphins, elephants, birds, rats, and others - show many signs of remembering their own pasts and how that helps them prepare for their futures. ${ }^{2}$ Individual humans not only share the ability to remember, but we can also share and pass on our memories in a process that David Christian calls collective learning. We can hold ideas about the past even when what we remember no longer exists. This ability was enhanced with cognitive developments that permitted symbolic thought. Vervet monkeys make distinct sounds that warn others in their troop of the presence and danger of eagles and leopards. ${ }^{3}$ What they do not do is to use these sounds in the absence of the referent. They do not sit around a campfire at night, with one apologizing, "I thought that I had seen an eagle today when I called out; and then it turned out that it was only a crow. Sorry for the false alarm." The evolution of the ability to hold a thought and then explicitly call it up by means of communicable assigned sounds is a milestone for hominins.

Memory of all kinds of things that no longer exist could often seem more important that what does exist now. We would remember our childhood caretakers long after they had died. Our memory of them was real to us even when they no longer existed. It was a

\footnotetext{
* I am grateful for the generous support from the Subvention of Publication Program of Villanova University for preparation of this article. I am also grateful to Lacy Loar-Gruenler for her editing of this article; of course any mistakes or errors are my reponsibility.
} 
short step to thinking that they as well as our memories of them lived on. Our memories became their spirits. In this, memory was tied to another cognitive explosion: imagination. We would imagine what never existed and then take steps to make those ideas physical. We can assume here that no one has seen their ancestors in the afterlife, but we have been taking steps to prepare them for it long before written history. There may or may not be a heaven, but there are graves in which people seem to have prepared their ancestors for the next world. Not only these people, but the goods they would need to live well in the next life had spirits. So we buried pots, weapons, jewelry, and other items with them. As it turned out, they could take it with them.

Another way to imagine came from the ability to put together memories of what we had seen to see something new in our mind's eye. An example of this is the Löwenmensch figurine or Lion-Man, a carving discovered in Germany in 1939 (see Figure 1). We can remember seeing a lion and a man, but never a creature that was both. Our ability to imagine a synthesis created a new idea, a new option of what might be. No one had ever seen a lion-man, but an artist from 35,000 to 40, ooo years ago could imagine and sculpt one from mammoth ivory. ${ }^{4}$ At that time, no one had ever seen a city or a computer, but eventually, imaginative people planned for and created them.

Memory and imagination opened up what could be real for us. It gave us options about what we have been a part of over time, as well as how we could participate in what came before - or what would come after us. What we remember and how we reflect on memory opens up new futures for us.

\section{Religious Histories}

We have many ways of how we go about keeping track of our memories. Methods of keeping track of days and other units such as months or years may have been developed as early as the
Neolithic period. The Wurdi Youang stone arrangement dating to between 11,000 and 20,000 years ago in Victoria, Australia, seems to have served this purpose. England's famous Stonehenge, built about 4,000 to 5,000 years ago, may have recorded and predicted the winter and summer solstices. A number of Maya constructions, such as the Caracol at Chichén Itzá, are aligned with a variety of celestial events that mark calendrical dates. These and many other examples indicate periods before writing when our ancestors saw themselves in relationship with the cosmos, with its events that had happened and could be expected to happen again. Memory and expectation were connected.

These cosmic events may have been thought to be associated with events on Earth, such as the appearance of certain plants, movements of herds, or the coming of rains. Cosmological observations and their association with local events developed into or often became part of ritual and religion. They were also useful in the recording of the passage of time. Religions

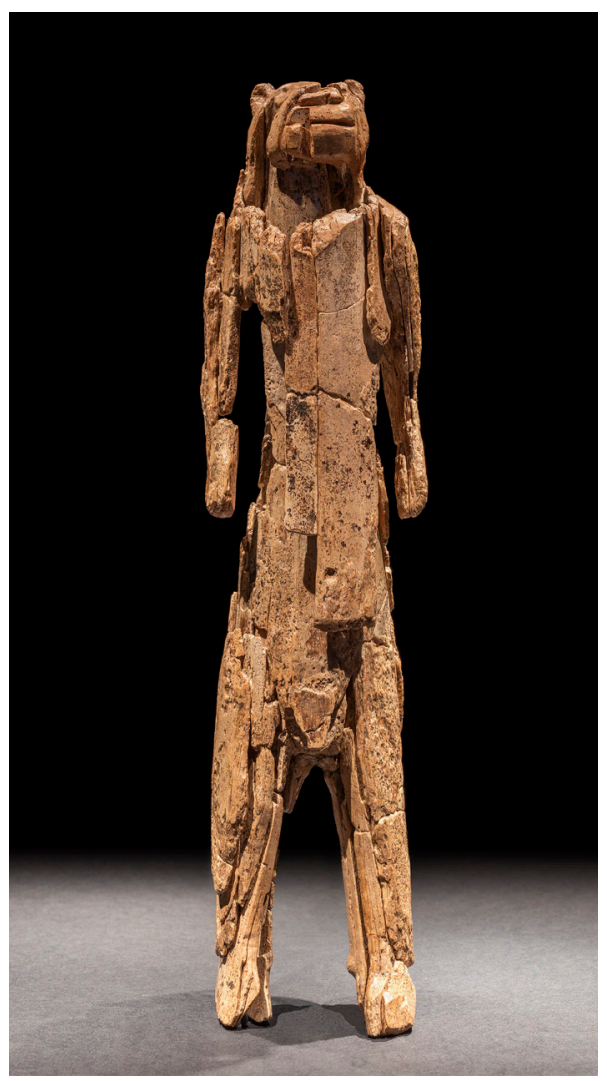

Figure 1: The Lion Man An Ice-Age Masterpiece often date time from an important event in their own histories or their understanding of the creation of the universe. This might have primarily to do with annual cycles that repeated themselves. Cyclical time has often been the norm. Sometimes, annual cycles were part of longer cycles. For example, the Maya had a count of 365 days in a year, (eighteen months each of twenty days, with a transitional month of five days) or Haab'. A katun of twenty years or 7,200 days, a baktun of 144,000 days, a thirteen baktun Long Count, and a 52 year long cycle, the Calendar Round, based on a comparison of the 260 ritual calendar with the Haab. They had other counts of days as well. The ancient Mayan long count began on the date for the most recent creation date, the equivalent of August 11, 3114 BCE in the Proleptic Gregorian calendar.

Other religious calendars also keep track of the passage of time. The calendars used officially in China before 1911 were primarily solarlunar cyclical calendars that corresponded to astronomical and seasonal events useful to farmers. There were also reign years, Huang $\mathrm{Li}$, associated with a number of the emperors. In the Hindu calendar, it is 5,122 years since Śrī Krșna returned to his eternal abode. In Buddhist calendars, the Buddha attained parinibbāna on or around 13 May 544 BCE. Yose ben Halafta, a Jewish rabbi from the $2^{\text {nd }}$ century $\mathrm{CE}$ calculated that the creation began in Elul 25 of Year 1 (3761 BCE). Maimonides, the twelfth-century Jewish philosopher and scientist, stated that the beginning of creation was in the Hebrew Year 0 (referred to as "Anno Mundi 0" in Latin), and that the creation of humans was in Anno Mundi 1, which corresponds to 3761 B.C.E." ${ }^{5}$ The current year $(2020 \mathrm{CE})$ in the Jewish calendar is 5780 .

A traditional date is the one used by the publication date of this issue: 2020 . This date had referred to the number of years since Christ's birth. St. Augustine (A.D. 354-430), in his work The Literal Meaning of Genesis (De Genesi ad litteram libri duodecim) argued that the Earth was about 6,ooo years old. ${ }^{6}$ James Ussher, a church leader in seventeenth century Ireland, roughly agreed with the date of creation still used for the Jewish calendar and by Augustine. Ussher's reading of Biblical and other ancient texts led him 
to establish the date of creation at "the entrance of the night preceding the 23rd day of October... the year before Christ 4004." 7 What mattered to Christians was not so much the creation of the world, but the recreation in Christ. As was written in the Christian Bible's epistle, 2 Corinthians $5: 17$, ". . . if anyone is in Christ, the new creation has come: The old has gone, the new is here!"

Beginning in the second century after Christ, some bishops in the Eastern Roman empire began counting years since the birth of Jesus. However, various scholars used different calendars to place Jesus' birth in slightly different years. The issue had not yet been settled even by three centuries later. Dionysius Exiguus, also known as Dennis the Little, was a monk originally from modern day Romania and Bulgaria who later worked in Rome. His primary concern was locating the dates of
Easter in different years within the annual liturgical calendar. He was the first to record that there was a date for an Easter 525 years after the birth of Christ, or in the Anno Domini, A.D., in theyear of our Lord. Some had previously stated that Christ had been born 5,500 years after the world had been created, and then predicted that Jesus would return in the year $6000 .{ }^{8}$ "The Era of the Incarnation . . . was soon much used in Italy and, to some extent, a little later in Spain; during the eighth and ninth centuries it was adopted in England. Charlemagne is said to have been the first Christian ruler to employ it officially. It was not until the tenth century that it was employed in the papal chancery." 9 This dating system now generally refers to the beginning of a secular Common Era (C.E.), or Before the Common Era (BCE) in place of one counting years Before Christ or in the Year of Our Lord. It keeps the numbers of years for convenience, but drops the religious starting point.

Islam too begins its count of years from a key event in its history. The Islamic calendar calculates 1441 years since the emigration of Muhammad from Mecca to Medina, known as the Hijra. For many centuries now, great numbers of people have placed themselves in time within these religious frameworks that stretch back millennia.

\section{Political, National, and Social Histories}

Political and National Histories

It is not always easy to distinguish between politics and religion, since they have often been so intertwined. Political leaders have often claimed some sort of religious status. Still, we can see how

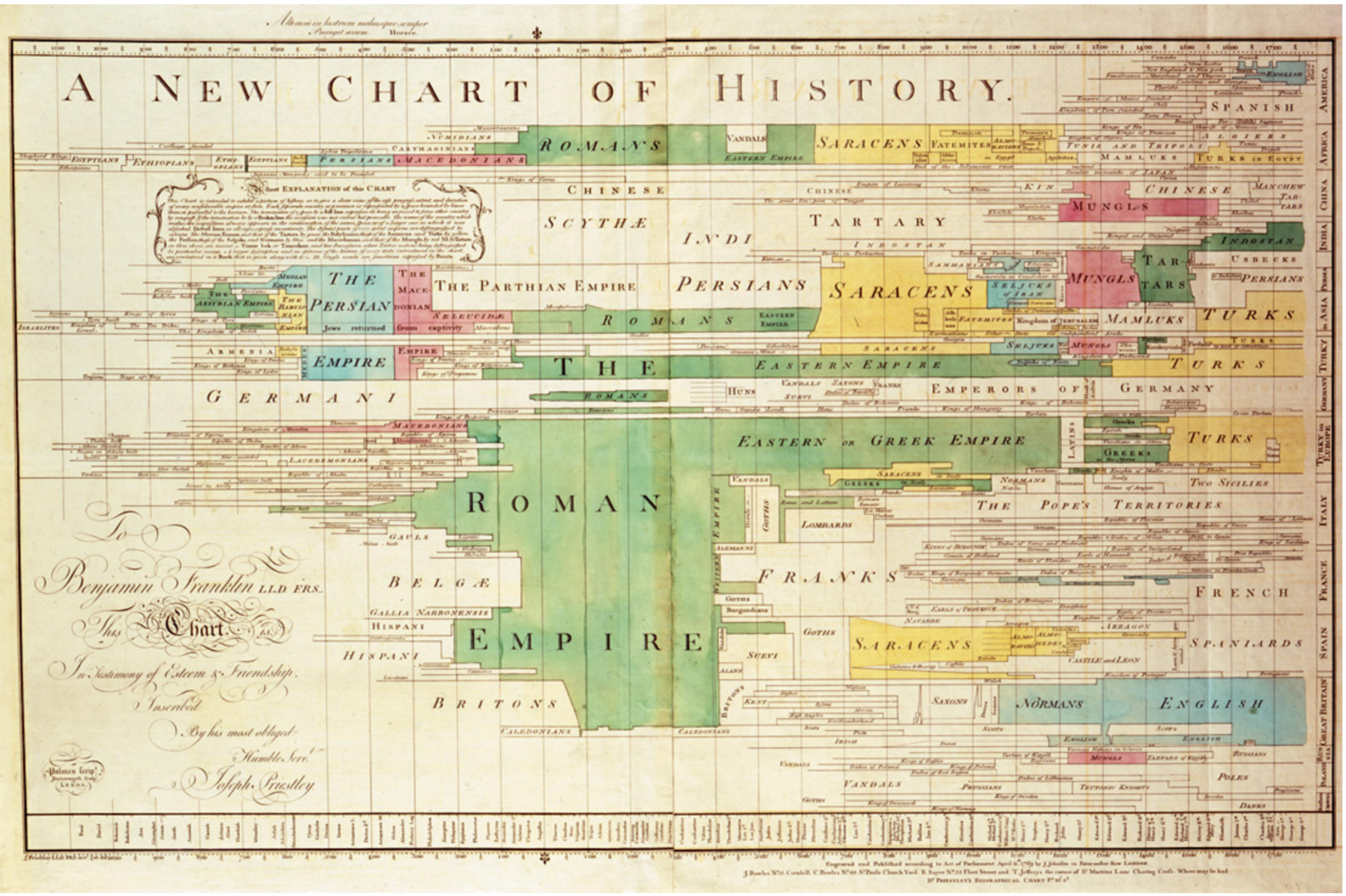

Figure 2. A New Chart of History. English: A color version of Joseph Priestly's A New Chart of History. "To Benjamin Franklin LLD. FRS. This Chart In Testimony of Esteem \& Friendship. Inscribed By his most obliged Humble Serv. Joseph Priestley. 1769.” 
the count of years in calendars has frequently been politically defined. It might begin with the coming to power of a leader or a dynasty, or in terms of national political histories.

During the Roman Republic, years too were dated by consulships. Dennis the Little wanted to change the common system of his time of counting years since the founding of Rome or since the coming to power of Diocletian, the Era of the Martyrs.

In European history, God's sovereignty gave way to dynastic sovereignty after the Peace of Westphalia in 1648. Under the principle of Cuius regio, eius religio (whose realm, his religion), loyal subjects accepted either Catholicism or the branch of Protestantism that their sovereign monarch held. Being a loyal subject of King Henry the VIII ${ }^{\text {th }}$ meant being a member of the Church of England that he headed. Especially with the French Enlightenment and Revolution, dynastic sovereignty gave way to national or popular sovereignty. Citizens of the nation were the people who held political sovereignty. The histories of nations more than dynasties or religions became what mattered. How and when did a nation originate and then develop?

One example of this is Joseph Priestley, an eighteenth-century English Separatist theologian, natural philosopher, chemist, and liberal political theorist. He has been credited with the discovery of oxygen, among other scientific accomplishments. In 1769, he dedicated his "New Chart of History" (see figure 2 previous page) to his friend and fellow politically active scientist, Benjamin Franklin. He did not begin with the creation of the world, a religious starting point, or the coming to power of a monarch. Instead of those types of beginning points for time frames, he began his history with the ancient nations of Israel and Egypt. To be sure, these were national starting points that happened to correspond to the inherited sense of time from the
Bible. But his chart did not mention Genesis, King David, or Djoser. His new account of history was global as well as national; it included many if not most of world great nations and some regions, such as those of Scandinavia, Poland, Russia, Great Britain, Spain, France, Italy, Turkey in Europe, Turkey in Asia, Germany, Persia, India, China, Africa and America.

The Republican Calendar (figure 3) sought to place the new regime in France after the French Revolution of 1789 within a newly devised time frame that was rational and freed from medieval superstition. It did not begin

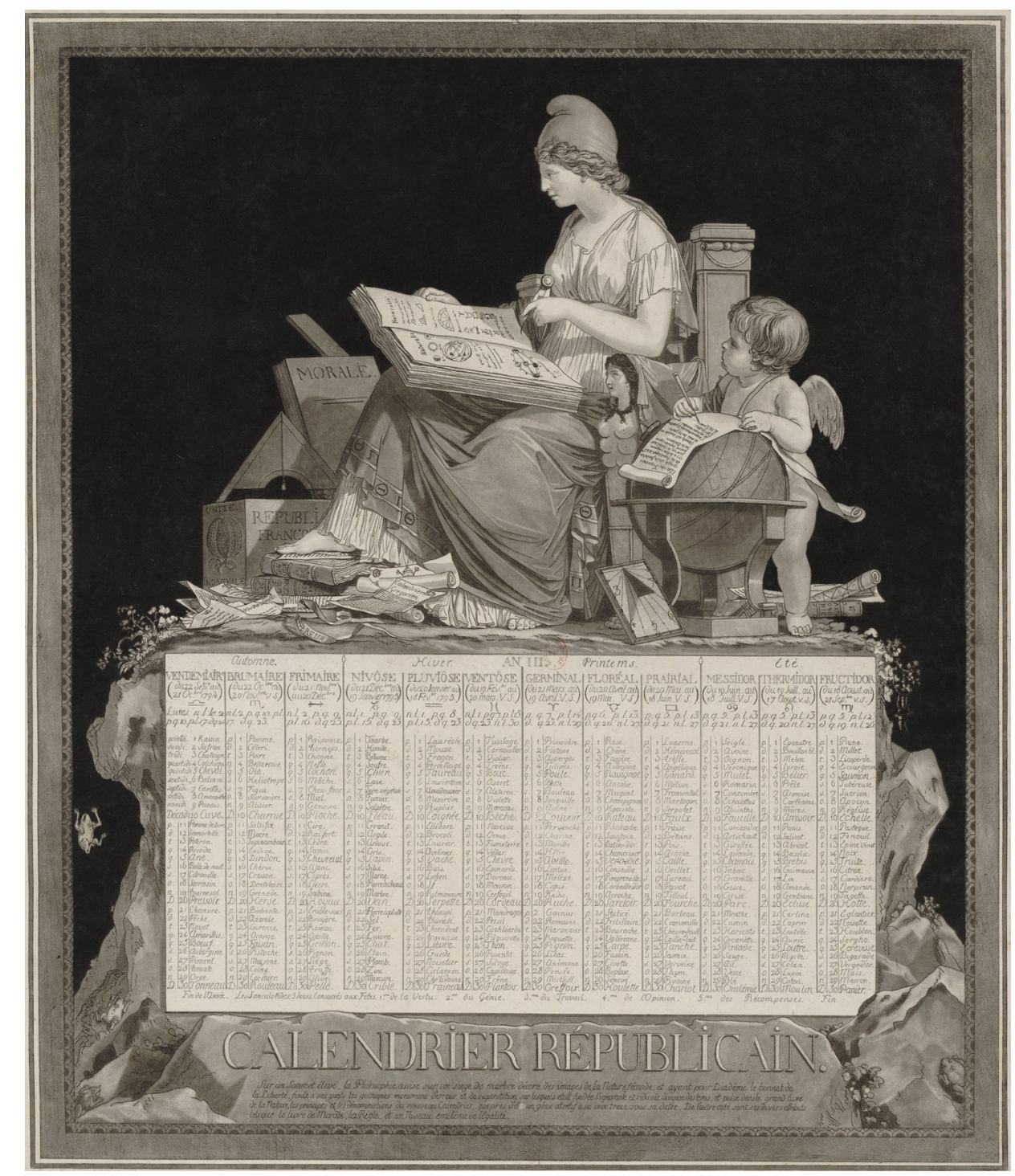

Figure 3. Calendrier républicain...: an III: [estampe] / P.L. Debucourt del. et sculp. 1794,

the record of time with Jesus' birth or ancient Israel. The count of years would begin with the momentous recent events in France. People disagreed if the count of years should begin with the Great Revolution of July 14, 1789, but those who favored beginning the count of years with that of the Republic on September 22, 1792 won the argument. Decimal time was considered more rational, so each day was to have ten hours, each with 100 minutes and each minute one hundred seconds. The limits to rationality and the respect for classical tradition left the number of years to use Roman numerals, such as 
An (Year) I or VI or X. The Republican calendar was used in France for 12 years from late 1793 to 1805 , and for 18 days by the Paris Commune in 1871.

The teaching of history in America never led to a new calendar, but for many, national history is the history that mattered. The nation's nearly sacred documents from 1776 and 1787 were almost Biblical in importance. As C. Bradley Thompson writes, Abraham Lincoln paraphrased Proverbs (25:11) and "asserted that the Declaration's liberty principle "was the word, 'fitly spoken' which has proved an 'apple of gold' to us." The Constitution was the "picture of silver" that "framed" the Declaration." ${ }^{\prime \prime}$ It was not God's creation of the world or the new creation in
Christ that seemed to engage many as much as the Manifest Destiny of the Republic in a New Land. The classical civil religion of America is where Walter A. McDougall begins his Tragedy of U.S. Foreign Policy." The papacy had its papal succession reaching back to Jesus; the United States has its constitutional dynasty begun with George Washington. The current latest occupant of the presidential succession is Donald Trump, the $45^{\text {th }}$ holder of the office. Some Americans took pride in the unbroken constitutional succession of power reaching back to 1789 .

American political identity is bound up with being aware of the history of the American national experience that was a key purpose of public education.
When the American Historical Association (AHA) was founded in 1884, history had only recently emerged as a distinct academic discipline. "The first few professors in the field of history had only been appointed at major universities in the 1870s." ${ }^{12}$ The country had survived its Civil War and the last spike of the transcontinental railroad had been driven in 1869 . The nation had achieved its Manifest Destiny of integrating territory from sea to shining sea. It was ready to tell its story. In 1872, John Gast painted his "American Progress," showing a woman with flowing blonde hair and billowing white robe flying like a goddess over settlers and developers who were replacing wild animals and peoples. ${ }^{13}$

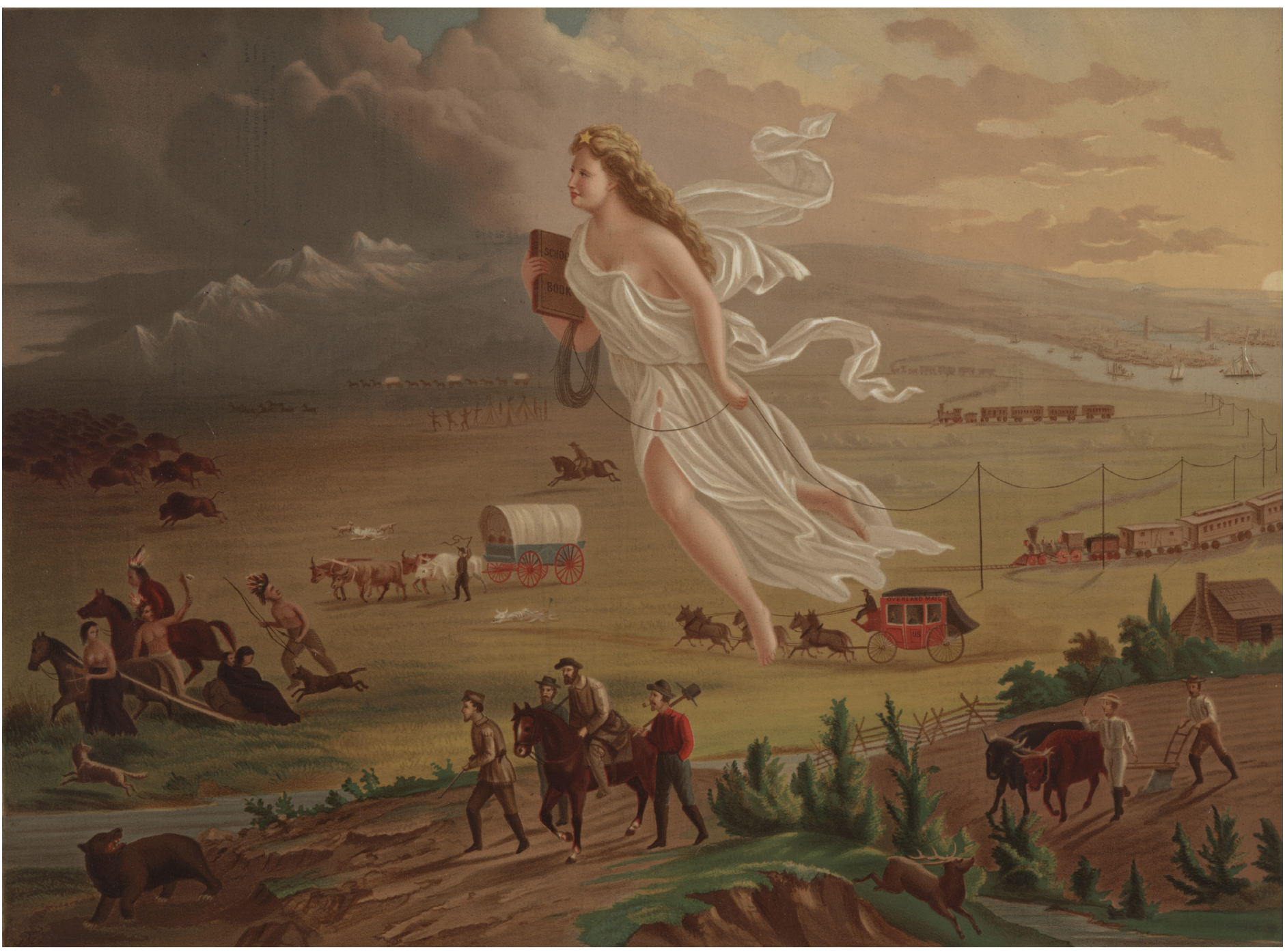

Figure 4. John Gast, American Progress, 1872. 
(Figure 4 previous page). The state was ready to sponsor public schools in part to foster nationalism and good citizenship. American history was on the curriculum, not the histories of all nations. Americans were not the only ones who celebrated their national histories. ${ }^{14}$ There are many histories of many nations whose purpose is to encourage national political identity. Heroic figures, great battles, and epic events form the origin stories of many nations - and the political identities of many citizens.

Similarly, the American Political Science Association was founded a few decades after the AHA, in 1903. The study of political science, like history, was associated with being American and even participating in American public life. Courses on the three branches of government were eventually supplemented by work on ethnic, class, and gender politics, along with many other sub-fields. Knowing about and understanding the events leading to - and the texts of - the Declaration of Independence, Constitution, Gettysburg Address, the Letter from a Birmingham Jail, and much else became part of being a good American citizen.

It was not only American political history that has been a commonly taught course and an important part of forming national identities. Courses on any number of other national, and sometimes regional histories, have been common: courses on British, French, Russian, Chinese, African, Latin American histories have been common in American universities and elsewhere. If students left with little else, they took away that it was nations that merited study. The time that each course used to begin a course varied significantly. The course normally began some centuries ago. In some cases, such as with courses on ancient Roman or Chinese history, the course might begin with events millennia ago.

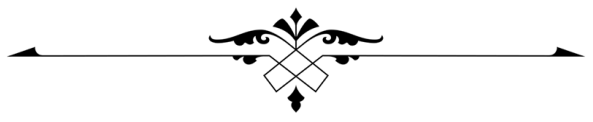

\section{Social Histories}

Over the past generation, the study and teaching about nations have fallen on hard times. As Jill Lepore observes, intellectuals "stopped studying the nation, believing that the nation-state was on the decline. The world had grown global, tied together by intricate webs of trade and accelerating forms of transportation and communication. The future was cosmopolitan, they insisted, not provincial. Why bother to study the nation?"15

Many historians began to move away from political and national histories in favor of investigating social history, or the histories of race, gender, class, and other categories of people at various pointswithin thelastdecades, centuries, or millennia. Studies of AfricanAmerican, Afro-Latinx, women, people from LGBTQ communities, and others became much more common. To these were added thematic histories, such as environmental histories. These were often told as part of an effort to give voice to the heretofore voiceless or understudied groups. Still, most national, political and even social histories were usually limited to the period of the written record of the human past.

Everyone has a story, not just important political leaders and great nations. If they did not fit neatly into a grand narrative, so much the better. Grand, all-encompassing narratives ended up just excluding marginalized groups and served the interests of the groups domineering the creation of culture.

\section{World History}

Some historians sought a larger framework than the study of nations, regime types, or social groups. Just over a century after the formation of the AHA, in 1982, some historians banded together in a World History Association to tell a story of globalization. These were histories of humanity at least since the dawn of agricultural societies. ${ }^{16}$ Historians comb archives filled with primary documents, perhaps going back even as far as ancient Sumer. By the time writing had developed in Sumer by 2700 BCE, there were different groups of people living on all continents and regions in the world except Antarctica. Peoples were speaking different languages and had developed distinct cultures; the now familiar physical differences among peoples were visible. Civilizational, regional, national, ethnic, and other differences were already well developed. Beginning the study of humans within this period of time leaves out a very long prelude.

Historians whose purpose is to foster a global political identity face the task of trying to build bridges among various pre-existing cultural identities. By starting the teaching of history within the past few thousand years, the story starts with well-established differences that have often led to conflicts. This approach begins with difference and often with distrust and hostility. What political identity would be formed if the starting points of political stories are pushed back before the origins of nations? If the human political story is shown to begin in Africa at least 200,000 years ago, then new human identities may be a result of courses on Human Politics in addition to those on American, British, Chinese, and other nations.

It may be that, welcomed or not, national histories have made a comeback in recent years. China, India, the United States, Britain, and others all seem to be keen on making their nations great again. Many have seen a new tribalism in the global wave of populism of recent years in which various social groups seek more impermeable boundaries. But others challenged and sought to expand on national, social, and even world histories.

\section{Big History}

William McNeill began his world history text with the revolution in food production between 8500 and 7000 B.C.. ${ }^{17}$ By doing so, he used sources other than archived writings. To discuss 
his topic, he had to refer to artifacts and archaeology. This opened a flood gate for some historians who learned from the natural sciences how to go beyond written materials in archives to examine the past that came before writing. These historians began to place the written record of the human past within the natural record of the entire known past. In doing so, they entered an intellectual world that geologists, astronomers, astrophysicists, chemists, biologists, physical anthropologists, and others had been developing for centuries. It was the natural scientists rather than the traditional historians and others in the humanities and social sciences who revolutionized our understanding of our place in the past. The past did not begin with the Epic of Gilgamesh in the Middle East some 4 , ooo years ago, the writings of the Bible or the pre-Socratics. Scientists learned how to read the stories told by light, stones, bones, and blood. And these stories were about times millions and billions of year ago. Humans were indeed formed from the same elements that are common on the surface of the Earth, but they were clearly not formed directly from a clump of clay. The first single cell organisms were formed from the elements and chemicals found on the Earth's crust. The carbon, hydrogen, amino acids, and proteins themselves had had long histories. As Carl Sagan so eloquently and famously observed, we are all made of star stuff. And then as Walter Alvarez and others argued, the star stuff was concentrated by Earth. ${ }^{18}$ And then it took billions of years of evolution between the first single cell organisms and humans.

Eric Chaisson, David Christian, Fred Spier and many others published evidence-based accounts of the periods of time reaching from the big bang 13.82 billion years ago, to those of stars and galaxies, chemicals, terrestrial planets like Earth, life, evolution, and human culture. History did not begin with nations, civilizations or even agriculture; it began with the beginning of time and space. ${ }^{19}$ In
2010, the International Big History Association was formed with the purpose of examining "the integrated history of the Cosmos, Earth, Life, and Humanity, using the best available empirical evidence and scholarly methods." The bulletin of the IBHA, Origins, as well as the organization's Journal of Big History, present writings and academic articles about these topics. ${ }^{20}$ David Christian, who coined the term Big History, published Origin Story: A Big History of Everything in 2018. ${ }^{21}$ It begins with the Big Bang and goes through the Anthropocene, or that current period of Earth's history during which humans have exerting the most pronounced effect on the planet.

Histories of nations from around the world challenged the idea that a single religion's idea is best to date all events. World history challenged the predominant idea of dividing humanity into national borders and social groups; it sought an integrated history of all of humanity since the agricultural revolution. Big history placed that human history into its own past of some 200,000 to 300,000 years, and then the many steps that had to be taken over 13.82 billion years in order to get to Earth, life, and humanity.

The new view of who we are, where we come from, and what we are a part of was reinforced by the Earthrise photo taken on December 24, 1968, by Apollo 8 astronaut William Anders. It is the photo that Fred Spier used for the cover of his book on Big History and the Future of Humanity. He has reflected on that photo ever since..$^{22}$ Seeing Earth from the vantage point of the moon changed who we are. The beautiful blue, white, and green Earth shown like a jewel in very black, foreboding space. There was no Planet B that we could escape to with our technology then or now if we manage to make our Earth uninhabitable. For many, old ideas of national security paled in comparison to global homeland security.

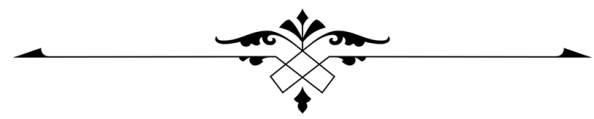

\section{SETI and a Coming of Age Story}

As striking as the view of the Earth from the moon was, many wondered if there were other habitable planets beyond our solar system. Mars had once been thought to be a possible homeland for intelligent life, but increasingly lent itself to questions about its hosting even microbial life. One of our best hopes is in the seas of one of Jupiter's moons, Io. The search for exoplanets (planets outside of our solar system), life anywhere in the universe beyond that on Earth, and extra-terrestrial intelligence all challenge and extend big history. Big history is not big enough for these fields. There are many planets other than Earth; as of 2019 over 4,0oo have been detected just within our local area of our own galaxy. ${ }^{23}$ The number of planets in the universe with over 100 billion galaxies must be phenomenal.

The interest in there possibly being many other planets has not been unique to our own time. German Cardinal Nicholas of Cusa suggested in the fifteenth century that there are other planets around other stars than our sun. He wrote that "The earth is a star like other stars, is not the centre of the universe, is not at rest, nor are its poles fixed. The celestial bodies are not strictly spherical, nor are their orbits circular."24 The sixteenth century Italian Dominican friar, Giordano Bruno, argued that stars were distant suns surrounded by their own planets, as well as that the universe is infinite and could have no center. (Figure 5, next page)

In 1685, the French author Bernard le Bovier de Fontenelle published Conversations on the Plurality of Worlds. He wrote it not in Latin, which was common for scholars of the time, but in French since his purpose was to make the ideas accessible to popular culture. ${ }^{25}$

A major difference between these early writings and SETI is the great scientific and technological advances made in recent times that permit us to look for physical evidence of exoplanets rather than just speculate about 


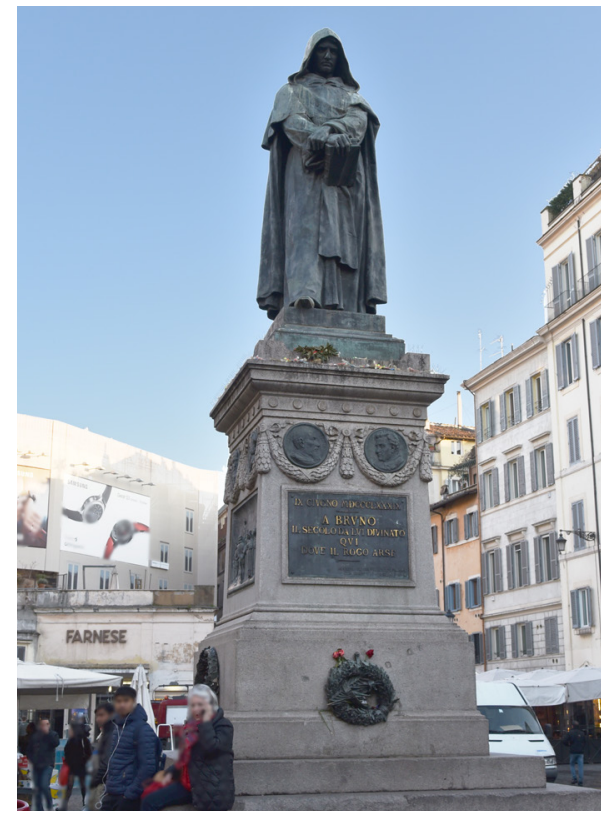

Figure 5: Location in Rome where on February 17, 1600, Giordano Bruno was burned at the stake for his heretical views.

Photo by Lowell Gustafson.

them. We can now use observation to establish that there are other habitable planets, that is, those with liquid water that can host life as we can imagine it.

We have successfully found evidence for exoplanets; we are still looking for evidence of any other life, much less intelligent life, beyond Earth. How likely it is that we will find evidence for it is still an open question. In 1961, Frank Drake wrote his famous equation that suggested what we needed to know before we could calculate how many life forms beyond Earth existed. It was:

where

$$
N=R_{*} \cdot f_{\mathrm{p}} \cdot n_{\mathrm{e}} \cdot f_{1} \cdot f_{\mathrm{i}} \cdot f_{\mathrm{c}} \cdot L
$$

$N=$ the number of civilizations in our galaxy with which communication might be possible (i.e. which are on our current past light cone);

and

$R_{*}=$ the average rate of star formation in our galaxy

$f_{\mathrm{p}}=$ the fraction of those stars that have planets

$n_{\mathrm{e}}=$ the average number of planets that can potentially support life per star that has planets

$f_{1}=$ the fraction of planets that could support life that actually develop life at some point

$f_{\mathrm{i}}=$ the fraction of planets with life that actually go on to develop intelligent life (civilizations)

$f_{\mathrm{c}}=$ the fraction of civilizations that develop a technology that releases detectable signs of their existence into space

$L=$ the length of time for which such civilizations release detectable signals into space

On Earth alone, there is almost an infinite variety of life forms in addition to humans. Would it be surprising if on the almost limitless number of planets within the universe there are many other life forms, including intelligent ones? Big history's interest in the cosmos is fine; its emphases on Earth, life on Earth, and humanity are just too myopic. We need to also think about and search for exoplanets, astrobiology, and exo-intelligence.

To many, it seemed very likely that with innumerable habitable planets, only a few of which we have discovered, there must be lots of extraterrestrial life forms. ${ }^{26}$ The great Italian-American physicist, Enrico Fermi, thought so too, but then, he asked, "So where is everybody?"27

\section{Detecting and Communication}

So far we have not yet detected extraterrestrial life or intelligence. An even more ambitious hope is that perhaps we might communicate with extraterrestrial life or form some sort of relationship with the other beings. ${ }^{28}$ And more ambitious yet is the idea of their visiting Earth or we traveling there. ${ }^{29}$ Given the enormous difficulties of travel over such distances, we certainly have no way now or in the near future of doing such. Other far more advanced civilizations may have figured it out, but there is no evidence that has persuaded scientists of such visits yet. We haven't even detected the far more likely radiation from civilizations beyond Earth.

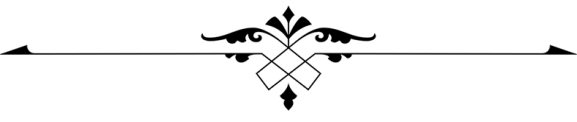

Coming of Age Story

Even though we have not found examples of the simple or intelligent life beyond Earth, the search is influential. For many centuries, we thought that our Earth was the center of the universe. We thought we were the only life forms in the cosmos. Even just a century ago, well after we learned that we orbited around the sun, most assumed that we were in the universe's only galaxy. It was not until Edwin Hubble and others proved that there were an enormous number of other galaxies that we realized that there were not just a few clouds or nebulae circling the Milky Way. Before 1995, we had no evidence of planets outside our solar system. Now we know there are thousands just within a few thousand light years of ours. We did not assume that we are all that exists. We have gone looking for and found other planets. We have gone looking for life beyond Earth and intelligent life beyond Earth - and we are still looking.

Imagining and searching for extraterrestrial life and intelligence represents the next level of complexity that big history had not before emphasized. Thestory of big history was already about the increasing complexity of relationships. History depended on the emergence of earlier relationships being incorporated into new, more complex ones with new properties. Big history presented a narrative of up and down quarks in relationship within neutrons and protons through the mediation of the strong force. Protons and neutrons formed relationships with electrons through the mediation of the electro-magnetic force. The dynamic equilibrium between gravity and nuclear fusion permitted stars to form nuclei with greater numbers of protons than hydrogen and helium had previously achieved. These elements, once spewed into space by dying stars or supernovae, connected within multi-element chemicals. With this process, plus neutron stars colliding with each other, heavier elements were available to form terrestrial planets. 
Some like Earth had multiple levels, with a metallic core, magma, a seafloor, continental plates, and much more. Chemistry evolved into bio-chemistry that evolved into the most complex sets of relationships to date within viruses and single cell prokaryote cells. These eventually became even more complex with new organelles and a nucleus in eukaryote cells. Multicellular life forms exploded into an almost infinite number of life forms in the Cambrian period. A devastating meteor may have caused the extinction of non-avian dinosaurs, and given mammals space to evolve eventually into homo sapiens. Relationships among individuals of our own kind went from nomadic kinship groups, to settled agricultural villages, to city states, nations, empires, and fragile global institutions. Now, with authors like H. G. Wells and SETI scientists, we could imagine a next level of inter-planetary, intergalactic relationships. The idea was as preposterous as the idea of a prokaryote cell would have been to the earliest carbon, hydrogen, and oxygen atoms.

There is an ironic effect in how we understand ourselves, life, and Earth as soon as we start to think about other planets and lifeforms and intelligent beings. Even if we do not find extraterrestrial life, the search matures us. We think about the origins of other planets, other life forms, other intelligent beings, and we do not exclusively think about our own origins. This process is not an origin story for us; it is a coming of age story. An individual person might be said to come of age with the realization that other persons exist independently and have their own ideas, emotions, and interests. Some experienced that maturation from a keen interest in the evolution of other species here on Earth. The line from life runs not only to humanity, as in the IBHA purpose statement, but to an almost infinite number of other species on and perhaps beyond Earth. ${ }^{\circ}$

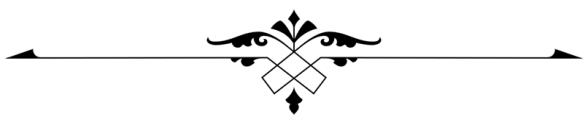

\section{Popular Culture}

Many people have not waited for mere evidence of extra-terrestrial life and intelligence to imagine what it might be and how it would affect us. Life forms and highly developed civilizations on other planets have caught our attention in a host of fictional sources, including novels, movies, comic books, television series, and songs.

Percival Lowell popularized the idea about intelligent life on Mars in his three books: Mars (1895), Mars and Its Canals (1906), and Mars As the Abode of Life (1908). ${ }^{31}$ Within two years of Lowell's 1895 book, H. G. Wells published his novel The War of the Worlds. In 1938, Orson Welles adapted and had the story performed on radio, causing widespread panic in the United States. $^{32}$

Sightings of UFOs were more common in the 1950s,33 but we still regularly get reports of them, with some suspicion that our government is suppressing knowledge about them for fear of the panic it would cause.

In 1966, the Byrds sang in "Mr. Spaceman" about:

... those strangers that come every night

Those saucer shaped lights put people uptight

Leave blue green footprints that glow in the dark

I hope they get home alright.

The Star Trek television series ran from 1966 - 69, and has retained devoted fans ever since. George Lucas' phenomenally successful series of movies, Star Wars, began in 1977. In 1982, we saw Steven Spielberg's magnificent movie, E.T. the ExtraTerrestrial. In 1997, Jodie Foster starred in Contact, based on Carl Saga's book by that name. No less enchanting was James Cameron's 2009 Avatar. Sandra Bullock and George Clooney ran into serious trouble in space in the 2013 film, Gravity. Matt Damon starred in The Martian in 2015. The list of popular accounts of extra-terrestrial life is extensive. $^{34}$ We seemingly cannot get enough of the fear, marvel, excitement, and wonder from the thought of what life forms on other planets might mean for us.

While these are often marvelously entertaining, they also often permit us to reflect on what discovery of extraterrestrial life would mean for us. Will we bicyclewith E.T.across theskyor fight Darth Vader in high-tech inter-galactic battles? In the 2016 documentary Stephen Hawking's Favorite Places, the famous astrophysicist warned us that "Meeting an advanced civilization could be like Native Americans encountering Columbus. That didn't turn out so well." ${ }^{35}$ Will the extraterrestrial life forms we discover just be microbes? Will they offer us new medicines or pandemic diseases? How do we imagine our relationship with them? There are serious reasons why we are fascinated by yet undiscovered extraterrestrial life.

\section{A Story of Endings}

Coming of age comes not only from a relationship, even if it is only speculative, with other planets' life forms. It also comes from a sense of mortality. Even if we do answer Fermi's paradox and find evidence of other intelligent life forms through detecting some sort of radio signals, our new found life forms are likely to be a great distance from us. We have only looked within 5,00o light years for habitable planets. Just our own galaxy is 100,00o light years across. We have barely begun to explore our own galaxy, much less the other hundred billion. If we get a signal from only a thousand light years away, it will take 2,00o years at best before we would get our reply to them and then their reply to us. That is a hardly the rate of communication on which to build a meaningful relationship. Any of us who heard their first signal and then send a reply will most certainly be long dead by the time they respond. Even more bothersome, will their civilization still exist when we do finally get our reply to them? Maybe they too are ravishing 
their own environment or blowing each other up. Will ours exist when we get their response? After just a handful of episodes in our dialogue with our new friends, it is more likely than we might want to admit that our species will be gone.

Admittedly, big history too has long been not only about origins; it has also been about endings. We listened to the astronomers and astrophysicists who talked about our sun becoming a Red Giant within five billion years, expanding until it evaporates Earth's oceans and fries any creature still hanging onto life. The coup de grace comes from dark energy which is pulling the galaxies in our universe apart. Many keep vanishing beyond an event horizon, never to be seen again by us. Given enough time, most of the galaxies in our universe will have sped out of our view, leaving us with a mostly black sky. And then, our own local galaxies and even matter might come apart. Chinua Achebe was even more right than he knew; things do indeed fall apart. ${ }^{6}$ Or things get ripped apart. In the long run, everything. In this view, the Big Rip follows the Big Bang. It is not only we as persons and as a species that will end, it is our solar system and our entire universe - perhaps.

We knew this possibility, but Origins

\section{Endnotes}

$1 \quad$ Sarah Abbott, "Plant Memory," Untamed Science, https:// untamedscience.com/biology/

plants/plant-memory/, last accessed December 18, 2019; Gagliano M et al. 2014. Experience teaches plants to learn faster and forget slower in environments where it matters. Oecologia, published online January 05, 2014; doi: 10.1007/s00442-013-2873-7; Robert Krulwich, "Can a Plant Remember? This One Seems to - Here's the Evidence," National Geographic, kept sounding more upbeat. Perhaps many of us who were rather long in the tooth were also like some teenagers who can be daredevils because they seem to think they are immortal. If we end our story with the Anthropocene, it almost suggests that this is a period that will go on forever. It won't. Homo sapiens have existed a mere two to three hundred thousand years. How long we will survive is anybody's guess, but is highly unlikely that we will be here until the Red Giant of our sun makes life on Earth impossible. The hopes that after we complete the destruction of our home planet we can migrate to some other is an idea that some have entertained. It is the stuff of science fiction for now. Discussing how humanity, life, Earth, and exoplanets will end is nobody's idea of a good time, but that is part of our Coming of Age Story.

More cheery views are of a multiverse with perhaps an infinite number of yet undiscovered universes beyond ours. Maybe our universe, like others no doubt, in a way give birth to other universes. Maybe ours has already dripped off new universes which never bother to get back in touch. Maybe ours won't rip apart, but will over a trillion years bounce back in an eternal cycle. Paul Steinhardt, Sean

December 15, 2015, https://www. nationalgeographic.com/science/ phenomena/2015/12/15/can-aplant-remember-this-one-seemsto-heres-the-evidence/; Sarah Laskow, "The Hidden Memories of Plants, Atlas Obscura, September 5, 2017, https://www.atlasobscura. com/articles/plant-memory-

hidden-vernalization, last accessed, December 18, 2019.

2 Frans de Waal, "The Surprising Complexity of Animal Memories" The Atlantic, June 2, 2019,
Carroll, Brian Greene and other serious astrophysicists do not end with gloom and doom about our universe's fate.

\section{Conclusions}

SETI challenges and expands on big history's purpose of examining the planet Earth, life on Earth, and humanity. It reminds us that a myriad of other life forms exist on Earth and that even more may exist on other planets. Homo sapiens - "wisemen" may be only one among many types of intelligent beings, each with their own long and complex histories. In a way, we have recovered our position at the center of the universe that we held in the Ptolemaic worldview. It is just now that all of the other planets and galaxies in our universe also began at the same point, and that from their viewpoint, everything else is expanding out from their location. Every place in the universe is the center of the universe. Every place - and every life form - has its own history that stretches back to the beginning of time. The Big Bang leads in steps to us and everything else. The study of Earth, Life, and Humanity needs to be a part of the study of exoplanets, astrobiology, all possible life, and all ways of being intelligent. The effort may help us discover and love our neighbor. https://www.theatlantic.com/ science/archive/2019/o6/ surprising-complexity-animalmemories/589420/, last accessed December 17, 2019; Panoz-Brown et al., 2018, "Replay of Episodic Memories in the Rat," Current Biology 28, 1628-1634, https:// doi.org/10.1016/j.cub.2018.04.006, last accessed December 17, 2019; Christine Dell-Amore, Dolphins have the longest memories in the animal kingdom, August 6, 2013, National Geographic, https:// www.nationalgeographic.com/ 
news/2013/8/130806-dolphinsmemories-animals-sciencelongest/, last accessed December 17, 2019 .

3 Klaus Zuberbühler, PredatorSpecific Alarm Calls in Campbell's Monkeys, Cercopithecus campbelli, Behavioral Ecology and Sociobiology, Vol. 50, No. 5 (Oct., 2001), pp. 414-422, https:// www.jstor.org/stable/4601985, last accessed December 16, 2019.

The Lion Man: an Ice Age masterpiece, The British Museum, https://blog.britishmuseum. org/the-lion-man-an-ice-agemasterpiece/, last accessed December 16, 2019.

5 David B. Green, This Day in Jewish History 3761 BCE: The World Is Created, According to the Hebrew Calendar and an Obscure Sage. Basing himself on no source but the bible, Rabbi Yose ben Halafta, who lived in the and century $\mathrm{CE}$, sat down and did the math. Haaretz, Oct 07, 2015, last accessed on December 10, 2019, https://www. haaretz.com/jewish/3761-bce-theworld-is-created-1.5405777.

6 Taylor, J.H., translation and annotation of St Augustine, The Literal Meaning of Genesis (Augustine, De Genesi ad Litteram), Vol. 1, Newman/Paulist Press, New York, 1982. Also see Augustine, The City of God, 12.10, 'Of the falseness of the history which allots many thousand years to the world's past', in Schaff, P. (Ed.), NPNF1-O2, ref 6, pp.232-233.

Ussher, James. Annales Veteris Testamenti, a prima mundi origine dedvcti: una cum rerum asiaticarum et cegyptiacarum chronico, a temporis historici principio usque ad Maccabaicorum initia producto. Londini, ex officina J. Flesher, \& prostant apud J. Crook \& J. Baker, 1650. Pdf. https://www.loc.gov/ item/21002221/. https://www.loc. gov/resource/rbctos.2017gen52659.

8 Declercq, Georges: Anno Domini. The Origins of the Christian Era. Turnhout Belgium. 2000.

9 Lersch, Chronologie, Freiburg, 1899, p. 233, cited in "Dionysius Exiguus," the Catholic Encyclopedia, http://www.newadvent.org/ cathen/o5010b.htm, last accessed on December 13, 2019.

10 Thompson, C. Bradley. America's Revolutionary Mind (p. xi). New York, Encounter Books, 2019.

11 McDougall, Walter A.. The Tragedy of U.S. Foreign Policy: How America's Civil Religion Betrayed the National Interest. New Haven, Yale University Press, 2016, p. 25.

12 "Brief History of the AHA," American Historical Association, accessed December 17, 2019, http:// www.historians.org/about-ahaand-membership/aha-history-andarchives/brief-history-of-the-aha.

13 John Gast, American progress, Library of Congress Prints and Photographs Division Washington, D.C. 20540 USA http://hdl.loc. gov/loc.pnp/pp.print, ppmsca 09855 http://hdl.loc.gov/loc.pnp/ ppmsca.09855, Reproduction Number: LC-DIG-ppmsca-09855 Library of Congress Prints and Photographs Division Washington, D.C. 20540 USA http://hdl.loc.gov/ loc.pnp/pp.print. Last accessed December 17, 2019.

14 Benedict Anderson, Imagined Communities: Reflections on the Origin and Spread of Nationalism (London: Verso,1991); Marc Ferro, The Use and Abuse of History: Or How the Past Is Taught to Children (London: Routledge, 2003); Ernest Gellner, Nations and Nationalism (Ithaca: Cornell University Press, 1983); Stephen J. Hartnett, Lisa B. Keranen, and Donovan Conley, eds., Imagining China: Rhetorics of Nationalism in an Age of Globalization (East Lansing, Michigan: Michigan State University Press, 2017); Derek Hastings, Nationalism in Modern Europe: Politics, Identity and Belonging since the French Revolution (London; New York: Bloomsbury Academic, 2017); Guntram Henrik Herb and David H. Kaplan, eds. Scaling Identities: Nationalism and Territoriality (Lanham, Maryland: Rowman \& Littlefield, 2018); John Hutchinson, Nationalism and War (New York: Oxford University Press, 2017); Fawcett Kohl, eds. Nationalism, Politics and the Practice of Archaeology (Cambridge University Press, 1996); Ronald Grigor Suny, "Constructing Primordialism: Old Histories for New Nations," The Journal of Modern History 73, no. 4 (December 2001): 862-896.

15 Jill Lpore, This America: The Case for the Nation, New York, Liveright Publishing Corporation, 2019, p.15.

16 A classic in this genre is William $\mathrm{H}$. McNeill, A World History, Oxford, Oxford University Press, 1979.

17 William H. McNeill, A World History, Oxford, Oxford University Press, 1967.

18 Olga García-Moreno, Luís Erick Aguirre-Palafox, Walter Álvarez, William Hawley. "A Little Big History of Iberian Gold," Journal of Big History, Volume 1, Issue 1, 2017, https://doi.org/10.22339/jbh. vii1.2243.

19 See, e.g. Craig Benjamin, Esther Quaedackers, David Baker, The Routledge Companion to Big History, New York, Routledge, 2020; Brown, Cynthia Stokes. Big History: From the Big Bang to the Present. New York: New Press: Distributed by W. W. Norton, 2007; Carroll, Sean. The Big Picture: On the Origins of Life, Meaning, and the Universe Itself. New York: Dutton, 2017; Chaisson, Eric. Epic of Evolution: Seven 
Ages of the Cosmos. New York: Columbia University Press, 2006; Christian, David. Maps of Time: An Introduction to Big History. The California World History Library. Berkeley: University of California Press, 2004; Christian, David, Cynthia Stokes Brown, and Craig Benjamin. Big History: Between Nothing and Everything. New York: McGraw Hill Education, 2014; Dartnell, Lewis. Origins: How Earth's History Shaped Human History, New York, Basic Books, 2019; Hazen, Robert. Genesis: The Scientific Quest for Life's Origin. Washington, DC: Joseph Henry Press, 2005; Hazen, Robert. The Story of Earth: The First 4.5 Billion Years, from Stardust to Living Planet. New York: Viking, 2012; Rodrigue, Barry, Leonid Grinin, Andrey Korotayev, co-editors, From Big Bang to Galactic Civilizations: A Big History Anthology. Delhi: Primus Books, 2015-2016. threevolumes; Shubin, Neil. The Universe Within: Discovering the Common History of Rocks, Planets, and People. New York: Pantheon Books, 2013; Shubin, Neil. Your Inner Fish: A Journey into the 3.5-Billion-Year History of the Human Body. New York, Vintage, 2008; Spier, Fred. Big History and the Future of Humanity. Chichester, West Sussex, UK: John Wiley \& Sons Inc., 2015; Volk, Tyler, Quarks to Culture: How We Came to $\mathrm{Be}$, New York, Columbia University Press, 2017.

20 Archived copies of Origins may be found at https://bighistory.org/ members/origins-bulletin/; the Journal of Big History is at https:// jbh.journals.villanova.edu/.

21 David Christian, Origin Story: A Big History of Everything, New York, Little, Brown and Company, 2018

22 Spier, F. (2019) On the social impact of the Apollo 8 Earthrise photo, or the lack of it? Journal of Big History, III(3); 117 - 150. https:// doi.org/10.22339/jbh.v3i3.3390, last accessed December 15, 2019.

23 Dennis Overbye, Search for Habitable Worlds Joined by New European Space Telescope, New York Times, December 18, 2019, https:// www.nytimes.com/2019/12/18/ science/cheops-satellite-launch.? action $=$ click \&module $=$ RelatedLin ks\&pgtype=Article, last accessed December 23, 2019; Exoplanet Exploration: Planets beyond our solar system, NASA, https:// exoplanets.nasa.gov/, last accessed on December 16, 2019; Campante, Tiago L., Nuno C. Santos, and Ma'rio J. P. F. G. Monteiro. Asteroseismology and Exoplanets: Listening to the Stars and Searching for New Worlds: IVth Azores International Advanced School in Space Sciences. Cham: Springer, 2018; Carroll, Michael. Earths of Distant Suns: How We Find Them, Communicate With Them, and Maybe Even Travel There. Cham: Springer International Publishing: Imprint: Copernicus, 2017; Exoplanet Discoveries: Have We Found Other Earths?: Joint Hearing Before the Subcommittee On Space \& Subcommittee On Research, Committee On Science, Space, and Technology, House of Representatives, One Hundred Thirteenth Congress, First Session, Thursday, May 9, 2013. Washington: U.S. Government Printing Office, 2013; Fontenelle, M. de 1657-1757., and John Glanvill. A Plurality of Worlds. London: Printed for R. Bentley and S. Magnes, 1688; Frank, Adam. Light of the Stars: Alien Worlds and the Fate of the Earth. New York, NY: W.W. Norton \& Company, 2018; Howard, Sethanne. "Exoplanets." Journal of the Washington Academy of Sciences 97, no. 3 (2011): 33-53; Kitchin, C. R. Exoplanets: Finding, Exploring, and Understanding Alien Worlds. New York, NY: Springer, 2012; Lemonick, Michael D. Mirror Earth: The Search for Our Planet's Twin. 1st U.S. ed.
New York: Walker, 2012; Sage, Leslie. "Exoplanets." Nature 513, no. 7518 (2014): 327; Seager, Sara. Exoplanets. Tucson: University of Arizona Press, 2011.

24 Nicholas of Cusa, Catholic Encyclopedia, https://www. catholic.org/encyclopedia/

view.php?id=8455, last accessed December 18, 2019; Nicholas of Cusa (1401-1464); also see The Internet Encyclopedia of Philosophy (IEP), https://www.iep.utm. edu/nicholas/\#H4, last accessed December 18, 2019.

25 A plurality of worlds written in French by the author of the Dialogues of the dead; translated into English by Mr. Glanvill. Fontenelle, M. de (Bernard Le Bovier), 1657-1757., Glanvill, John, 1664?-1735. London: Printed for R. Bentley and S. Magnes, 1688. https://quod.lib.umich.edu/e/ eebo/A39871.0001.001?view=toc, last accessed, December 18, 2019.

Asimov, Isaac. Extraterrestrial Civilizations. New York: Crown Publishers, 1979; Dick, Steven J. Plurality of Worlds: The Origins of the Extraterrestrial Life Debate From Democritus to Kant. Cambridge [Cambridgeshire]; New York: Cambridge University Press, 1982; Dick, Steven J. Life On Other Worlds: The 2oth-century Extraterrestrial Life Debate. Cambridge; New York: Cambridge University Press, 1998; Hamilton, Joseph. The Starry Hosts: A Plea for the Habitation of the Planets. London: Edinburgh: Simpkin, Marshall; A. Elliott, [etc.], 1875; Jayawardhana, Ray. Strange New Worlds: The Search for Alien Planets and Life Beyond Our Solar System. Princeton, N.J.: Princeton University Press, 2011; Linde, Peter. The Hunt for Alien Life: A Wider Perspective. 1st edition 2016. Cham: Springer International Publishing: Imprint: Springer, 2016; Macvey, John W. Whispers From Space. New 
York: Macmillan, 1973; Morrison, Philip., John Billingham, and John Wolfe. The Search for Extraterrestrial Intelligence, SETI. [Washington, D.C.]: National Aeronautics and Space Administration, Scientific and Technical Information Office, 1977; Regis, Edward. Extraterrestrials: Science and Alien Intelligence. Cambridge [Cambridgeshire] ; New York: Cambridge University Press, 1985; Ross, Monte. The Search for Extraterrestrials: Intercepting Alien Signals. Berlin ; New York : Chichester, UK: Springer; published in association with Praxis, 2009; SETI: Search for Extra-terrestrial Intelligence. Washington, D.C.: Moffett Field, Calif.: Pasadena, Calif:: Washington, D.C.: National Aeronautics and Space Administration; Ames Research Center, SETI Office; Jet Propulsion Laboratory, California Institute of Technology, SETI Office ; NASA Headquarters, Office of Space Sciences and Applications, Life Sciences Division, 1990; Shuch, H. Paul. Searching for Extraterrestrial Intelligence: SETI Past, Present, and Future. Berlin; Heidelberg; New York: Chichester: Springer; Praxis Publishing, 2011; Squeri, Lawrence. Waiting for Contact: The Search for Extraterrestrial Intelligence. Gainesville, Florida: University Press of Florida, 2016; Traphagan, John. Extraterrestrial Intelligence and Human Imagination: SETI At the Intersection of Science, Religion, and Culture. Cham: Springer, 2014; Vakoch, Douglas A., and Albert A. Harrison. Civilizations Beyond Earth: Extraterrestrial Life and Society. New York: Berghahn Books, 2011; Waldrop, M. Mitchell. "The Search for Alien Intelligence: SETI Is Dead ? Long Live SETI." Nature 475, no. 7357 (2011): 442-444; Wall, Michael. Out There: A Scientific Guide to Alien Life, Antimatter, and Human Space Travel (For the Cosmically Curious). Grand Central
Publishing, New York, 2018.

27 Milan M. Cirkovic: The Great Silence: The Science and Philosophy of Fermi's Paradox: Oxford University Press, Great Clarendon Street, Oxford $\mathrm{OX}_{2}$ 6DP, United Kingdom, 2018; Davies, P. C. W. The Eerie Silence: Renewing Our Search for Alien Intelligence. 1st U.S. ed. Boston: Houghton Mifflin Harcourt, 2010; Webb, Stephen. If the Universe Is Teeming With Aliens ... Where Is Everybody?: Seventy-five Solutions to the Fermi Paradox and the Problem of Extraterrestrial Life. 2nd Ed. Springer, 2015.

28 Hippke, Michael. "Interstellar Communication: The Colors of Optical SETI." Journal of Astrophysics and Astronomy 39, no. 6 (2018): 1-16; Vakoch, Douglas A. Communication With Extraterrestrial Intelligence. Albany: State University of New York Press, 2011.

29 Haswell, Carole A. Transiting Exoplanets. Cambridge: Cambridge University Press, 2010.

30 This point is made regarding species on Earth at https://opentreeoflife. github.io/, as described by Mark Fischetti, All 2.3 Million Species Are Mapped into a Single Circle of Life Lineages of all known species on Earth are finally pieced together, Scientific American, March 1, 2016, https://www.scientificamerican. com/article/all-2-3-million-speciesare-mapped-into-a-single-circle-oflifeı/, last accessed April 16, 2020.

31 Percival Lowell, Mars, Boston, Houghton, Mifflin, 1896, https://archive.org/details/ marsbypercivallooolowe/page/ n8; Mars and its canals, New York, The Macmillan company; London, Macmillan \& co., ltd., 1906, https://archive.org/details/ marsanditscanaloılowegoog/page/ n13; Mars as the Abode of Life, New
York, The Macmillan company, 1908, https://archive.org/details/ agg9438.00o1.oo1.umich.edu/page/ n2, last accessed, December 20, 2019.

32 H. G. Wells, The War of the Worlds, Last Updated: September 20, 2019, Project Gutenberg, https://www. gutenberg.org/files/36/36-h/36-h. htm, the original 1938 broadcast is available at various locations, including https://www.youtube. $\mathrm{com} /$ watch?v=997tN7MhQ4 $\mathrm{I}$, last accessed December 16, 2019.

33 E.g., Donald Keyhoe, Flying Saucers from Outer Space, New York, Henry Holt 1953.

34 See, e.g. Extraterrestrial life in popular culture, https:// en.wikipedia.org/wiki/Category: Extraterrestrial_life_in_popular_ culture; List of films featuring extraterrestrials, https:// en.wikipedia.org/wiki/List_of_ films_featuring_extraterrestrials; Songs about extraterrestrial life, https://en.wikipedia. org/wiki/Category:Songs_ about_extraterrestrial_life; Books about extraterrestrial life, https://en.wikipedia.org/ wiki/Category:Books_about_ extraterrestrial_life, last accessed December 20, 2019.

35 Michael Greshko, Stephen Hawking's Most Provocative Moments, From Evil Aliens to Black Hole Wagers: The famous physicist was fond of making scientific bets and predictions, from the nature of black holes to the end of humanity. National Geographic, May 2, 2018. https://www.nationalgeographic. com/news/2018/o3/stephenhawking-controversial-physicsblack-holes-bets-science/\#close, last accessed April 16, 2020.

36 Achebe, Chinua. The African Trilogy. (London: Everyman's Library, 2010) ISBN 9781841593272. 
Edited with an introduction by Chimamanda Ngozi Adichie. Things Fall Apart, No Longer at Ease, and Arrow of God in one volume. 